\title{
Pengaruh Kecerdasan Emosional, Gaya Belajar Visual, Gaya Belajar Auditorial Dan Kinestetik Pada Tingkat Pemahaman Akuntansi
}

\author{
Ni Made Inten Pramesti ${ }^{1}$ \\ Fakultas Ekonomi dan Bisnis \\ Universitas Udayana, Indonesia \\ Email: pramestinten01@gmail.com
}

\author{
Ni Made Dwi Ratnadi ${ }^{2}$ \\ Fakultas Ekonomi dan Bisnis \\ Universitas Udayana, Indonesia
}

\begin{abstract}
ABSTRAK
Tingkat pemahaman akuntansi dipengaruhi oleh kecerdasan emosional, gaya belajar visual, gaya belajar auditorial dan gaya belajar kinestetik yang ada dalam diri mahasiswa. Tujuan penelitian untuk mengetahui pengaruh kecerdasan emosional, gaya belajar visual, gaya belajar auditorial dan gaya belajar kinestetik pada tingkat pemahaman akuntansi. Penelitian dilakukan di Fakultas Ekonomi dan Bisnis Universitas Udayana. Responden adalah 171 mahasiswa jurusan program S1 akuntansi angkatan 2015. Berdasarkan hasil analisis, kecerdasan emosional berpengaruh positif pada tingkat pemahaman akuntansi hal ini menunjukkan semakin baik kecerdasan emosional yang dimiliki mahasiswa menyebabkan tingkat pemahaman akuntansi meningkat. Gaya belajar visual, auditorial dan kinestetik berpengaruh positif pada tingkat pemahaman akuntansi hal ini menunjukkan semakin baik gaya belajar maka semakin tinggi tingkat pemahaman akuntansi. Implikasi hasil penelitian ini mendukung teori kognitif yang menyatakan tingkat pemahaman akuntansi di pengaruhi oleh faktor internal.
\end{abstract}

Kata Kunci: Pemahaman; Kecerdasan; Gaya Belajar.

\section{Influence of Emotional Intelligence, Visual Learning Style, Auditorial and Kinesthetic Learning Styles at the Understanding of Accounting}

\begin{abstract}
The level of one's accounting understanding can be influenced by emotional intelligence, visual, auditory and kinesthetic learning styles that exist within students. The purpose of the study to determine the effect of emotional intelligence, visual, auditory and kinesthetic learning styles on the level of understanding of accounting. The research was conducted at the Faculty of Economics and Business, Udayana University. Respondents were 171 students majoring accounting undergraduate program 2015. Based on the results of the analysis, emotional intelligence has positive effect on the level of accounting understanding. Visual, auditory and kinesthetic learning style have positive effect on the level of understanding of accounting, this shows the better the learning style, the higher the level of understanding of accounting. The implications of the results of this study support cognitive theory which states the level of understanding of accounting is influenced by internal factors.
\end{abstract}

Keywords: $\quad$ Understanding, Intelligence, Learning Style

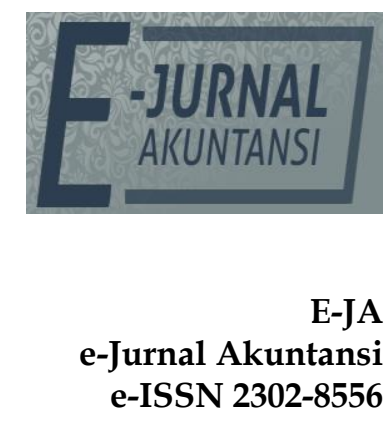

Vol. 30 No. 1

Denpasar, Januari 2020

Hal. 130-146

Artikel Masuk:

7 Juni 2019

Tanggal Diterima: 11 Desember 2019 


\section{PENDAHULUAN}

Tingkat pemahaman akuntansi merupakan bagaimana seorang individu dapat mengerti dan paham terhadap apa yang sudah dipelajari yang berhubungan dengan mata kuliah akuntansi, serta bisa menalarkan pencatatan dan transaksi suatu kesatuan ekonomi. Mahasiwa dapat dikatakan menguasai atau memahami akuntansi apabila mata kuliah akuntansi yang sudah diperolehnya selama ini dapat diterapkan dalam kehidupan bermasyarakat atau dengan kata lain dapat dipraktekkan di dunia kerja (Dewi \& Wirama, 2016). Tanda seorang mahasiswa memahami akuntansi tidak hanya ditunjukkan dari nilai-nilai yang didapatkannya dalam mata kuliah akuntansi tetapi juga apabila mahasiswa tersebut mengerti dan dapat menguasai konsep-konsep yang terkait (Fred et al., 2012)

Ketidakjelasan pada industri akuntansi yang dihasilkan oleh pendidikan tinggi akuntansi, hal ini dikarenakan banyak perguruan tinggi tidak mampu membuat anak didiknya menguasai dengan baik pengetahuan dan keterampilan hidup (Tucker, 2014) (Junifar, 2015). Soft skill telah lama diperbincangkan oleh akademisi, pengajar tidak hanya mengajarkan keterampilan teknis saja namun sudah mengembangkan ke pelatihan umum (Salehi, 2016). Mahasiswa terbiasa dengan pola belajar menghafal tetapi tidak memahami pelajaran tersebut, sehingga mahasiswa akan cenderung mudah lupa dengan apa yang pernah dipelajari atau kesulitan untuk memahami apa yang diajarkan. Pengetahuan yang dibutuhkan untuk akuntan terdiri dari pengetahuan umum, organisasi, bisnis dan akuntansi (Peker \& Mirasyedioglu, 2008).

Tabel 1 menyajikan nilai mahasiswa berkaitan dengan mata kuliah akuntansi. Tabel 1 menunjukkan bahwa rata-rata nilai mata kuliah dari nilai $\mathrm{A}$ sampai dengan $\mathrm{D}$ yang berkaitan dengan akuntansi. Mahasiswa yang mendapatkan nilai A sebesar $49,5 \%$ dan nilai B sebesar $44,0 \%$ artinya mahasiswa tersebut paham terhadap akuntansi, namun mahasiswa yang mendapat nilai $\mathrm{C}$ sebesar 4,8 dan nilai $\mathrm{D}$ sebesar $1,7 \%$ artinya mahasiswa tersebut belum memahami akuntansi. Hal ini dikarenakan pemahaman mahasiswa masih kurang yang artinya dalam aktivitas perkuliahan seharusnya dibutuhkan konsentrasi penuh guna mendapatkan hasil yang maksimal. Padahal konsentrasi sangat dibutuhkan dan mempengaruhi hasil belajar yang dicapai, konsentrasi belajar merupakan suatu kefokusan diri pribadi mahasiswa akuntansi terhadap mata kuliah ataupun aktivitas belajar serta aktivitas perkuliahan. Dalam aktivitas perkuliahan seharusnya dibutuhkan konsentrasi penuh untuk mendapatkan hasil belajar yang memuaskan.

Terdapat beberapa faktor yang mempengaruhi dalam mewujudkan konsentrasi penuh, salah satunya yaitu adanya minat, perhatian dan kecerdasan emosional. Brackett et al. (2011) menyatakan bahwa kecerdasan emosional adalah seluruh kemampuan yang mempengaruhi bagaimana individu memanfaatkan emosi untuk memfasilitasi pemikiran atau mengatur emosi untuk fokus pada informasi yang penting. Kemampuan-kemampuan ini sangat dapat mendukung dalam mencapai tujuan dan cita-citanya. Hal ini juga sesuai dengan pernyataan dari Nath et al. (2015) dan Artana (2014) yang menyatakan kecerdasan emosional menggambarkan sejumlah kompetensi yang berkaitan dengan kemampuan 
untuk mengontrol emosi dalam rangka untuk memotivasi, memprioritaskan hal yang penting dan untuk tujuan dalam hidup (Akbar et al., 2011).

Tabel 1. Nilai Mahasiswa Berkaitan dengan Mata Kuliah Akuntansi

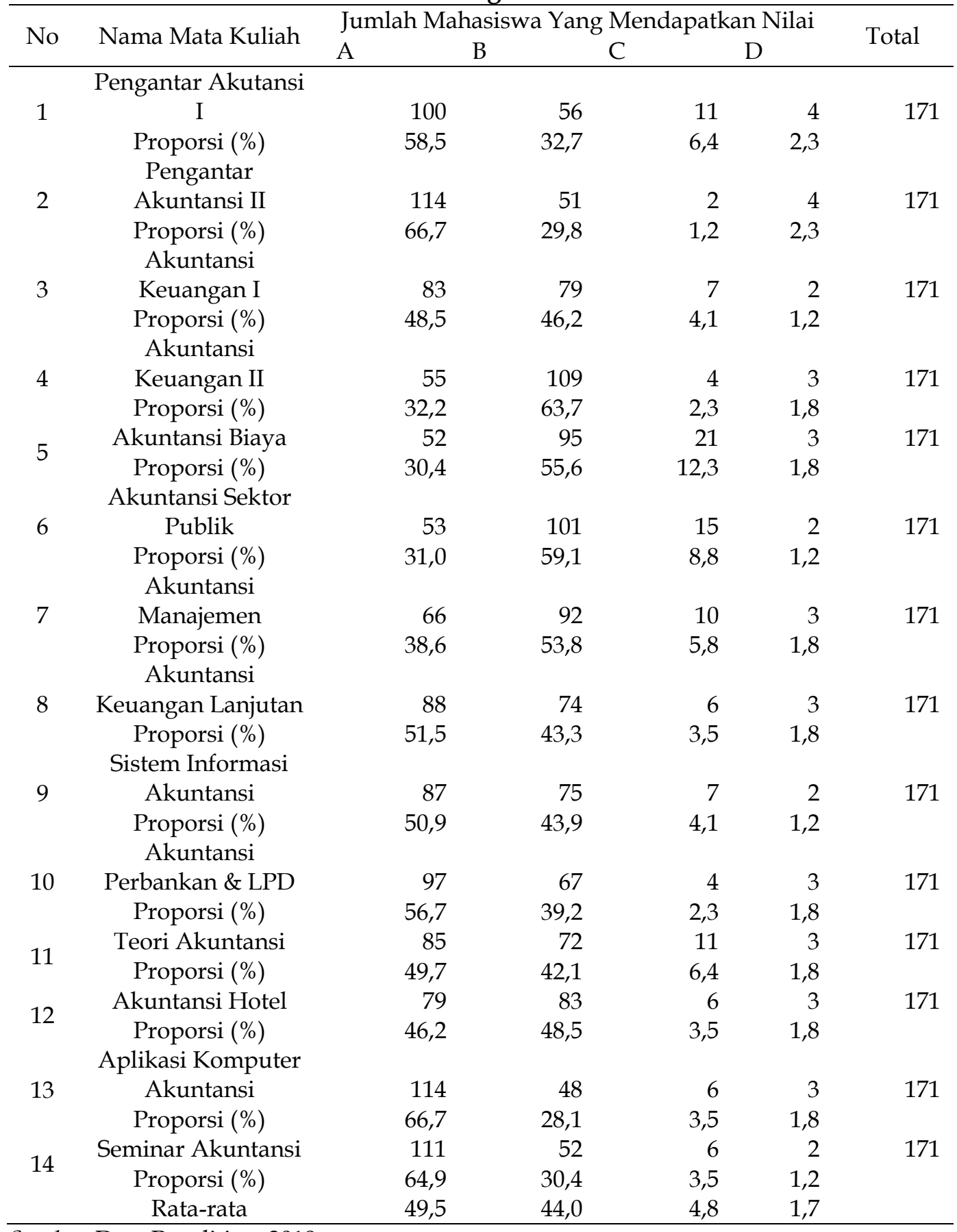

Sumber: Data Penelitian, 2019

Faktor berikutnya adalah gaya belajar. Gaya belajar merupakan cara yang dipilih seseorang untuk menggunakan kemampuannya. Gaya belajar berhubungan dengan cara seseorang belajar, serta cara belajar yang disukai. Mahasiswa akan merasakan gaya belajar mudah yang berbeda-beda. Setiap mahasiswa memiliki gaya belajar yang berbeda, apapun cara yang dipilih, 
perbedaan gaya belajar menunjukkan cara tercepat dan terbaik bagi setiap individu untuk bisa menyerap sebuah informasi dari luar dirinya.

Gaya belajar kinestetik merupakan gaya belajar dengan cara bergerak, bekerja, dan menyentuh. Pratiwi (2014) mengatakan hanya 30 persen mahasiswa yang berhasil mengikuti pembelajaran di kelas karena mereka mempunyai gaya belajar yang sesuai dengan gaya mengajar yang diterapkan dosen di dalam kelas. Sisanya, sebanyak 70 persen mahasiswa mengalami kesulitan dalam mengikuti pembelajaran di kelas karena mereka memiliki gaya belajar lain, yang tidak sesuai dengan gaya mengajar yang diterapkan di dalam kelas. Artinya, 70 persen gaya mahasiswa tidak terakomodasi oleh gaya mengajar dosen dalam pembelajaran.

Berdasarkan teori kognitif menyatakan bahwa proses pemikiran dan perbedaan kondisi mental serta pengaruh faktor internal dan eksternal dalam menentukan hasil belajarnya seorang individu, faktor internalnya meliputi kecerdasan emosional yang artinya kemampuan lebih yang dimiliki seseorang dalam memotivasi diri, ketahanan dalam menghadapi kegagalan, mengendalikan emosi dan menunda kepuasan, serta mengatur keadaan jiwa. Kecerdasan emosional dalam seseorang mampu untuk mengetahui dan menanggapi perasaan mereka sendiri dengan baik dan mampu membaca dan menghadapi perasaan-perasaan orang lain dengan efektif. Hal ini berarti mahasiswa akuntansi yang memiliki kecerdasan emosional yang baik akan lebih mudah dalam berkonsentrasi dan bertanggung jawab terhadap lingkungan disekitarnya sehingga tingkat pemahaman akuntansinya lebih baik, oleh karena itu ia akan berhasil dalam kehidupan dan memiliki motivasi untuk berprestasi.

Penelitian Ariantini (2014), Visser (2015), Santoso, (2018), Sinarti \& Sari (2019) dan Khajeh et al. (2014) yang menyatakan bahwa kecerdasan emosional berpengaruh positif pada tingkat pemahaman akuntansi. Junifar (2015) menyatakan bahwa kecerdasan emosional berpengaruh positif pada tingkat pemahaman akuntansi. Satria (2017) menyatakan bahwa kecerdasan emosional berpengaruh positif terhadap tingkat pemahaman akuntansi. Berdasarkan uraian tersebut, maka dapat dibuat hipotesis sebagai berikut :

$\mathrm{H}_{1}$ : Kecerdasan emosional berpengaruh positif pada tingkat pemahaman akuntansi.

Berdasarkan teori kognitif menyatakan bahwa proses pemikiran dan perbedaan kondisi mental serta pengaruh faktor internal dan eksternal dalam menentukan hasil belajarnya seorang individu, faktor internalnya meliputi gaya belajar visual yang artinya kekuatan gaya belajar ini terletak pada indera penglihatan (mata). Gaya belajar dengan cara melihat, mengamati, memandang, dan sejenisnya (Bire, 2014). Bagi orang yang memiliki gaya belajar ini, indera mata adalah alat yang paling peka untuk menangkap setiap gejala atau stimulus (rangsangan) belajar. Mahasiswa yang memiliki gaya belajar visual secara tidak lagsung lebih sering membaca dan mencatat sesuatu lebih detail (Chen et al., 2018). Gaya belajar visual yang dimiliki akan mempengaruhi mahasiswa dalam menangkap dan memahami mata kuliah yang diajarkan, termasuk pemahaman akuntansi (Arif, 2017). Ardila (2015) dan Kustiani \& Brihandhono (2017) menyatakan bahwa gaya belajar visual berpengaruh terhadap belajar akuntansi. Berdasarkan uraian tersebut, maka dapat dibuat hipotesis sebagai berikut : 
$\mathrm{H}_{2}$ : Gaya belajar visual berpengaruh positif pada tingkat pemahaman akuntansi. Berdasarkan teori kognitif menyatakan bahwa proses pemikiran dan perbedaan kondisi mental serta pengaruh faktor internal dan eksternal dalam menentukan hasil belajarnya seorang individu, faktor internalnya meliputi gaya belajar auditorial yang artinya seseorang dengan gaya belajar ini, lebih dominan dalam menggunakan indera pendengaran untuk melakukan aktivitas belajar (Bire et al., 2014). Mahasiswa dengan gaya belajar ini lebih menekankan pada pendengaran untuk memahami mata kuliah yang diajarkan (Arif, 2017). Oleh karena itu, mahasiswa sangat mengandalkan telinganya untuk mencapai kesuksesan belajar, misalnya dengan cara mendengar seperti mendengarkan ceramah, radio, berdialog, dan berdiskusi. (Shoemaker et al., 2015) Selain itu, bisa juga mendengarkan melalui nada (Ihsan \& Diem, 2016). Orang yang bertipe auditorial, mudah mempelajari bahan-bahan yang disajikan dalam bentuk suara (ceramah), begitu dosen menerangkan ia cepat menangkap bahan pelajaran, disamping itu kata dari teman (diskusi) atau suara radio lebih mudah menangkapnya (Nzesei, 2015).

Gaya belajar auditorial berpengaruh positif terhadap pemahaman akuntansi mahasiswa oleh karena itu, gaya belajar auditorial lebih dominan dalam menggunakan indera pendengaran untuk melakukan aktivitas belajar agar memudahkan dalam memahami akuntansi seperti mengikuti seminar dan kerja kelompok menyatakan bahwa terdapat pengaruh antara gaya belajar auditorial terhadap pemahaman akuntansi (Ramlah, 2014) Berdasarkan uraian tersebut, maka dapat dibuat hipotesis sebagai berikut:

$\mathrm{H}_{3}$ : Gaya belajar auditorial berpengaruh positif pada tingkat pemahaman akuntansi.

Berdasarkan teori kognitif menyatakan bahwa proses pemikiran dan perbedaan kondisi mental serta pengaruh faktor internal dan eksternal dalam menentukan hasil belajarnya seorang individu, faktor internalnya meliputi gaya belajar kinestetik yang artinya gaya belajar dengan cara bergerak, bekerja, dan menyentuh (Bire, 2014). Gaya belajar ini mengharuskan individu yang bersangkutan menyentuh sesuatu yang memberikan informasi tertentu agar bisa mengingat dan mehamami akuntansi tersebut (Arif, 2017). Orang dengan gaya belajar ini lebih mudah menangkap pelajaran apabila ia bergerak, meraba, atau mengambil tindakan. Misalnya dengan cara terjun langsung untuk melakukan praktek di lapangan atau perusahaan agar mengetahui lingkungan disekitarnya (Polat et al. 2015).

Individu yang bertipe ini, mudah mempelajari bahan yang berupa tulisantulisan, gerakan-gerakan, dan sulit mempelajari bahan yang berupa suara atau penglihatan. Selain itu, belajar secara kinestetik berhubungan dengan praktik atau pengalaman belajar secara langsung. Orang yang menggunakan gaya belajar kinestetik memperoleh informasi dengan mengutamakan indera perasa dan gerakan-gerakan fisik. Arif (2017) dan Syofyan \& Siwi (2018) menyatakan bahwa gaya belajar kinstetik berpengaruh terhadap pemahaman akuntansi. Berdasarkan uraian tersebut, maka dapat dibuat hipotesis sebagai berikut:

$\mathrm{H}_{4}$ : Gaya belajar kinestetik berpengaruh positif pada tingkat pemahaman akuntansi. 


\section{METODE PENELITIAN}

Penelitian ini dilakukan dengan menggunakan pendekatan kuantitatif dengan tingkat eksplanasi penelitian berbentuk asosiatif. Penelitian ini dilakukan di Fakultas Ekonomi dan Bisnis Universitas Udayana dengan menyebarkan kuesioner kepada mahasiswa jurusan akuntansi program S1 angkatan 2015. Objek penelitian ini adalah kecerdasan emosional, gaya belajar visual, gaya belajar auditorial dan gaya belajar kinestetik pada tingkat pemahaman akuntansi mahasiswa jurusan akuntansi program S1 angkatan 2015 di Fakultas Ekonomi dan Bisnis Universitas Udayana. Variabel bebas dalam penelitian ini adalah kecerdasan emosional $\left(X_{1}\right)$, gaya belajar visual $\left(X_{2}\right)$, gaya belajar auditorial $\left(X_{3}\right)$ dan gaya belajar kinestetik $\left(\mathrm{X}_{4}\right)$.

Kecerdasan emosional adalah kemampuan seseorang untuk mengenali emosi diri, mengelola emosi, memotivasi diri sendiri, mengenali emosi orang lain (empati) dan kemampuan untuk membina hubungan (kerjasama) dengan orang lain. Kecerdasan emosional merupakan kemampuan seseorang dalam mengenali emosi diri dan mengkoordinasi emosi diri sesuai dengan kebutuhan. Salah satu faktor yang mempengaruhi motivasi mahasiswa adalah kepercayaan diri. Mahasiswa yang mempunyai kepercayaan diri tinggi, akan cenderung memiliki motivasi yang tinggi pula karena mahasiswa percaya akan kemampuan yang dimilikinya, dibandingkan mahasiswa yang tidak memiliki kepercayaan diri akan cenderung tidak memiliki motivasi karena mahasiswa tidak yakin akan kemampuannya sendiri (Thomas, 2002).

Gaya belajar visual adalah gaya belajar yang menitik beratkan pada ketajaman penglihatan (Khalid, 2011). Bukti-bukti konkret harus diperlihatkan terlebih dahulu agar mereka paham gaya belajar ini mengandalkan penglihatan atau melihat terlebih dahulu buktinya untuk kemudian bisa mempercayainya (Isnaeni, 2017).

Gaya belajar auditorial adalah gaya belajar dengan mengandalkan pendengaran untuk bisa memahami dan mengingat. Gaya belajar seperti ini benar-benar menempatkan pendengaran sebagai alat utama menyerap informasi atau pengetahuan. Artinya, kita harus mendengar lalu bisa mengingat dan memahami informasi itu (Isnaeni, 2017). Gaya belajar kinestetik adalah gaya belajar ini mengaruskan individu yang bersangkutan menyentuh sesuatu yang memberikan informasi tertentu agar bisa mengingatnya (Isnaeni, 2017).

Variabel terikat dari penelitian ini adalah tingkat pemahaman akuntansi. Tingkat pemahaman akuntansi mahasiswa dinyatakan dengan seberapa mengerti seorang mahasiswa terhadap apa yang sudah dipelajari dalam konteks ini mengacu pada mata kuliah akuntansi. Pemahaman akuntansi adalah bagaimana seorang individu dapat mengerti dan paham terhadap apa yang sudah dipelajari yang berhubungan dengan mata kuliah akuntansi, serta bisa menalarkan pencatatan dan transaksi suatu kesatuan ekonomi. Tanda seorang mahasiswa memahami akuntansi dapat ditunjukkan dari nilai-nilai yang didapatkan dalam mata kuliah akuntansi yang diajarkan.

Mengukur tingkat pemahaman akuntansi dinyatakan dengan nilai yang berkaitan dengan mata kuliah akuntansi yaitu Pengantar Akuntansi I, Pengantar Akuntansi II, Akuntansi Keuangan I, Akuntansi Keuangan II, Akuntansi Biaya, Akuntansi Sektor Publik, Akuntansi Manajemen, Akuntansi Keuangan Lanjutan, 
Sistem Informasi Akuntansi, Akuntansi Perbankan dan LPD, Teori Akuntansi, Akuntansi Hotel, Aplikasi Komputer Akuntansi, dan Seminar Akuntansi. Satuan pengukuran yang digunakan adalah skal likert. Dimana pengukuran menggunakan skala likert dari nilai D (point 1) sampai dengan nilai A (point 4).

Data kuantitatif meliputi data skor jawaban kuesioner yang terkumpul dan jumlah mahasiswa jurusan akuntansi program S1 angkatan 2015 di Fakultas Ekonomi dan Bisnis Universitas Udayana. Pada penelitian ini data kualitatif berupa daftar pernyataan-pernyataan yang terdapat dalam kuesioner. Sumber data pada penelitian ini adalah mahasiswa jurusan akuntansi program S1 angkatan 2015 Fakultas Ekonomi dan Bisnis Universitas Udayana.

Data ini berupa kuesioner yang telah diisi oleh mahasiswa jurusan akuntansi program S1 angkatan 2015 Fakultas Ekonomi dan Bisnis Universitas Udayana yang telah menjadi responden pada penelitian ini. Data penelitian ini diperoleh dengan menggunakan metode tinjauan kepustakaan (library research) dan mengakses website manapun situs-situs.

Populasi dalam penelitian ini adalah seluruh mahasiswa reguler pagi dan reguler sore jurusan akuntansi program S1 angkatan 2015 di Fakultas Ekonomi dan Bisnis Universitas Udayana. Mahasiswa jurusan akuntansi program S1 angkatan 2015 dipilih karena mahasiswa jurusan akuntansi program S1 angkatan 2015 telah berada diakhir masa perkuliahan sehingga diharapkan telah memiliki gambaran mengenai manfaat maksimal dari proses belajar akuntansi. Jumlah mahasiswa jurusan akuntansi program S1 reguler pagi dan reguler sore angkatan 2015 di Fakultas Ekonomi dan Bisnis Universitas Udayana di sajikan dalam Tabel 2.

Tabel 2. Jumlah Mahasiswa Jurusan Akuntansi Angkatan 2015

\begin{tabular}{ccc}
\hline No & Kelas & Jumlah \\
\hline 1 & Reguler Pagi & 146 \\
2 & Reguler Sore & 152 \\
& Total & 298 \\
\hline
\end{tabular}

Sumber: Data Penelitian, 2019

Metode penentuan sampel dalam penelitian ini adalah dengan menggunakan metode probability sampling dengan teknik random sederhana. Jumlah sampel pada masing-masing program dapat dilihat pada Tabel 3 berikut ini.

Tabel 3. Jumlah Sampel Pada Masing-Masing Program

\begin{tabular}{ccc}
\hline Program & Perhitungan & Hasil \\
\hline Reguler Pagi & $146 / 298 \times 171=83,7$ & 84 \\
Reguler Sore & $152 / 298 \times 171=87,2$ & 87 \\
& Total & 171 \\
\hline
\end{tabular}

Sumber : Data Penelitian, 2019

\section{HASIL DAN PEMBAHASAN}

Responden dalam penelitian ini adalah mahasiswa program S1 jurusan akuntansi angkatan 2015 yang berjumlah 171 orang. Data dikumpulkan melalui survey dengan menyebarkan kuesioner pada mahasiswa jurusan akuntansi angkatan 2015 di Fakultas Ekonomi dan Bisnis Universitas Udayana secara langsung kepada individu yang bersangkutan. 
Peneliti telah menyebarkan kuesioner sebanyak 171 eksemplar dengan tingkat pengembalian responden 100 persen dan tingkat pengembalian dapat di analisis sebesar 100 persen. Data pengambilan dan pengembalian sampel dapat dilihat pada Tabel 4 berikut ini.

Tabel 4. Data Pengambilan Dan Pengembalian Sampel

\begin{tabular}{|c|c|}
\hline Uraian & $\begin{array}{c}\text { Jumlah } \\
\text { Kuesioner }\end{array}$ \\
\hline Total kuesioner yang disebar & 171 \\
\hline Kuesioner dikembalikan & 171 \\
\hline Kuesioner yang dibatalkan & 0 \\
\hline Kuesioner yang digunakan dalam analisis & 171 \\
\hline Tingkat pengembalian (response rate) $=171 / 171 \times 100 \%$ & $100 \%$ \\
\hline Tingkat penggunaan (usable response rate) $=171 / 171 \times 100 \%$ & $100 \%$ \\
\hline
\end{tabular}

Sumber : Data Penelitian, 2019

Tabel 4 menunjukkan bahwa jumlah kuesioner yang disebarkan kepada responden sebanyak 171 kuesioner, yang dikembalikan sebanyak 171 kuesioner dan setelah diperiksa semua kuesioner layak digunakan untuk analisis selanjutnya. Karakteristik responden merupakan data responden yang dikumpulkan untuk mengetahui profil responden. Dari hasil kuesioner yang dilakukan terhadap responden, maka dapat diketahui profil responden yang meliputi jenis kelamin dan IPK (Indeks Prestasi Kumulatif) terakhir. Ringkasan karakteristik responden dapat dilihat pada Tabel 5 berikut ini.

Proporsi mahasiswa laki-laki berjumlah 48 orang (28,0 persen), sedangkan proposi mahasiswa perempuan berjumlah 123 orang (71,9 persen) yang artinya bahwa proporsi mahasiwa perempuan lebih banyak mengisi kuesioner penelitian dibandingkan proporsi mahasiswa laki-laki.IPK digunakan untuk mengetahui tingkat pemahaman akuntansi responden. Jumlah responden yang memiliki IPK lebih kecil dari 3 berjumlah 1 orang (0,58 persen). Responden yang memiliki IPK 3-3,5 berjumlah 54 orang (31,5 persen). Responden yang memiliki IPK lebih besar dari 3,5 berjumlah 116 orang (67,8 persen).

Tabel 5. Karakteristik Responden

\begin{tabular}{llcc}
\hline & \multicolumn{2}{c}{ Jumlah } \\
No & \multicolumn{1}{c}{ Karakteristik Responden } & Orang & Presentase (\%) \\
\hline 1 & Jenis Kelamin & & \\
& Laki-laki & 48 & 28,0 \\
& Perempuan & 123 & 71,9 \\
& Total & 171 & 100 \\
2 & IPK & & \\
& $<3$ & 1 & 0,58 \\
& $3-3,5$ & 54 & 31,5 \\
& $>3,5$ & 116 & 67,8 \\
& Total & 171 & 100 \\
\hline
\end{tabular}

Sumber : Data Penelitian, 2019

Hasil uji validitas menunjukkan bahwa seluruh instrumen penelitian yang digunakan untuk mengukur variabel kecerdasan emosional, gaya belajar visual, gaya belajar auditorial, gaya belajar kinestetik, dan tingkat pemahaman akuntansi memiliki nilai koefisien korelasi dengan skor total seluruh item pernyataan lebih besar dari 0,30 dengan signifikansi kurang dari 0,05. Hal ini 
menunjukkan bahwa butir-butir pernyataan dalam instrument penelitian tersebut valid dan layak digunakan sebagai instrument penelitian.

Tabel 6. Rekapitulasi Hasil Uji Reliabilitas Instrumen Penelitian

\begin{tabular}{lcc}
\hline \multicolumn{1}{c}{ Variabel } & Cronbach's Alpha & Keterangan \\
\hline Kecerdasan emosional $\left(\mathrm{X}_{1}\right)$ & 0,754 & Reliabel \\
Gaya belajar visual $\left(\mathrm{X}_{2}\right)$ & 0,807 & Reliabel \\
Gaya belajar auditorial $\left(\mathrm{X}_{3}\right)$ & 0,773 & Reliabel \\
Gaya belajar kinestetik $\left(\mathrm{X}_{4}\right)$ & 0,801 & Reliabel \\
Tingkat pemahaman akuntansi $(\mathrm{Y})$ & 0,766 & Reliabel \\
\hline
\end{tabular}

Sumber : Data Penelitian, 2019

Hasil uji reliabilitas menunjukkan bahwa seluruh instrumen penelitian memiliki koefisien Cronbach's Alpha lebih dari 0,60. Jadi dapat dinyatakan bahwa seluruh variabel telah memenuhi syarat reliabilitas atau kehandalan sehingga dapat digunakan untuk melakukan penelitian. Hasil uji reliabilitas instrumen penelitian dapat dilihat pada Tabel 6 .

Tabel 7. Hasil Uji Statistik Deskriptif

Std.

\begin{tabular}{lrrrrr}
\multicolumn{1}{c}{ Variabel } & N & Minimum & Maximum & \multicolumn{1}{c}{ Mean } & Deviation \\
\hline Kecerdasan Emosional & 171 & 2,290 & 4,000 & 3,420 & 0,363 \\
$\left(X_{1}\right)$ & 171 & 2,000 & 4,000 & 3,337 & 0,466 \\
Gaya Belajar Visual $\left(X_{2}\right)$ & 171 & 1,000 & 4,000 & 3,373 & 0,470 \\
Gaya Belajar Auditorial & & & & & \\
$\left(X_{3}\right)$ & 171 & 1,250 & 4.000 & 3,273 & 0,533 \\
$\begin{array}{l}\text { Gaya Belajar Kinestetik } \\
\left(X_{4}\right)\end{array}$ & 171 & 1,070 & 4,000 & 3,414 & 0,461 \\
$\begin{array}{l}\text { Tingkat Pemahaman } \\
\text { Akuntansi }(Y)\end{array}$ & & & &
\end{tabular}

Sumber : Data Penelitian, 2019

Tabel 7 menyajikan hasil uji statistik deskritif. Variabel kecerdasan emosional memiliki nilai minimum 2,290, nilai maksimum 4,000 dan nilai ratarata sebesar 3,420. Nilai standar deviasi variabel kecerdasan emosional sebesar 0,363 . Hal ini berarti berdasarkan hasil statistik deskritif terjadi perbedaan nilai kecerdasan emosional yang diteliti terhadap nilai rata-ratanya sebesar 0,363 dan nilai standar deviasi lebih rendah dibandingkan dengan nilai rata-rata, yang artinya sebaran data terkait kecerdasan emosional sudah merata. Variabel gaya belajar visual memiliki nilai minimum 2,000, nilai maksimum 4,000 dan nilai rata-rata sebesar 3,337. Nilai standar deviasi variabel gaya belajar visual sebesar 0,466. Hal ini berarti berdasarkan hasil statistik deskritif terjadi perbedaan nilai gaya belajar visual yang diteliti terhadap nilai rata-ratanya sebesar 0,466 dan nilai standar deviasi lebih rendah dibandingkan dengan nilai rata-rata, yang artinya sebaran data terkait gaya belajar visual sudah merata.

Variabel gaya belajar auditorial memiliki nilai minimum 1,000, nilai maksimum 4,000 dan nilai rata-rata sebesar 3,373. Nilai standar deviasi variabel gaya belajar auditorial sebesar 0,470. Hal ini berarti berdasarkan hasil statistik deskritif terjadi perbedaan nilai gaya belajar auditorial yang diteliti terhadap nilai rata-ratanya sebesar 0,470 dan nilai standar deviasi lebih rendah dibandingkan dengan nilai rata-rata, yang artinya sebaran data terkait gaya belajar auditorial sudah merata. Variabel gaya belajar kinestetik memiliki nilai 
minimum 1,250, nilai maksimum 4,000 dan nilai rata-rata sebesar 3,273. Nilai standar deviasi variabel gaya belajar kinestetik sebesar 0,533. Hal ini berarti berdasarkan hasil statistik deskritif terjadi perbedaan nilai gaya belajar kinestetik yang diteliti terhadap nilai rata-ratanya sebesar 0,533 dan nilai standar deviasi lebih rendah dibandingkan dengan nilai rata-rata, yang artinya sebaran data terkait gaya belajar kinestetik sudah merata.

Variabel tingkat pemahaman akuntansi memiliki nilai minimum 1,070, nilai maksimum 4,000 nilai rata-rata sebesar 3,414. Nilai standar deviasi variabel tingkat pemahaman akuntansi 0,461. Hal ini berarti berdasarkan hasil statistik deskriptif terjadi perbedaan nilai tingkat pemahaman akuntansi terhadap nilai rata-ratanya sebesar 0,461 dan standar deviasi lebih rendah dibandingkan dengan nilai rata-rata, yang artinya sebaran data terkait tingkat pemahaman akuntansi sudah merata.

Tabel 8. Hasil Uji Normalitas

\begin{tabular}{llr}
\hline \multicolumn{2}{c}{ Model } & Unstandardized Residual \\
\hline N & & 171 \\
Normal Parameters & Mean & 0,000 \\
& Std. Deviation & 5,253 \\
Most Extreme Differences & Absolute & 0,147 \\
& Positive & 0,093 \\
& Negative & 0,147 \\
Kolmogorov-Smirnov Z & & 1,926 \\
Asymp. Sig. (2-tailed) & & 0,601 \\
\hline
\end{tabular}

Sumber : Data Penelitian, 2019

Nilai signifikansi sebesar 0,601 seperti yang ditunjukkan oleh Tabel 8 . Karena nilai signifikansi uji Kolmogorov-Smirnov lebih dari 0,05 maka dapat disimpulkan bahwa model persamaan regresi tersebut berdistribusi normal.

Tabel 9. Hasil Uji Multikolinearitas

\begin{tabular}{lccc}
\hline \multicolumn{1}{c}{ Variabel } & Tolerance & VIF & Keterangan \\
\hline Kecerdasan emosional $\left(\mathrm{X}_{1}\right)$ & 0,628 & 1,592 & Bebas multikol \\
Gaya belajar visual $\left(\mathrm{X}_{2}\right)$ & 0,613 & 1,631 & Bebas multikol \\
Gaya belajar auditorial $\left(\mathrm{X}_{3}\right)$ & 0,925 & 1,081 & Bebas multikol \\
Gaya belajar kinestetik $\left(\mathrm{X}_{4}\right)$ & 0,923 & 1,083 & Bebas multikol \\
\hline
\end{tabular}

Sumber : Data Penelitian, 2019

Nilai tolerance dan VIF dari seluruh variabel tersebut menunjukkan bahwa nilai tolerance untuk setiap variabel lebih besar dari 10\% dan nilai VIF lebih kecil dari 10 yang berarti model persamaan regresi bebas dari multikolinearitas seperti yang ditunjukkan oleh Tabel 9.

Tabel 10. Hasil Uji Heteroskedastisitas

\begin{tabular}{lcc}
\hline \multicolumn{1}{c}{ Variabel } & Signifikansi & Keterangan \\
\hline Kecerdasan emosional $\left(\mathrm{X}_{1}\right)$ & 0,273 & Bebas heteroskedastisitas \\
Gaya belajar visual $\left(\mathrm{X}_{2}\right)$ & 0,868 & Bebas heteroskedastisitas \\
Gaya belajar auditorial $\left(\mathrm{X}_{3}\right)$ & 0,096 & Bebas heteroskedastisitas \\
Gaya belajar kinestetik $\left(\mathrm{X}_{4}\right)$ & 0,500 & Bebas heteroskedastisitas \\
\hline
\end{tabular}

Sumber : Data Penelitian, 2019

Nilai signifikansi dari variabel kecerdasan emosional, gaya belajar visual, gaya belajar auditorial, dan gaya belajar kinestetik, masing-memiliki nilai yang lebih besar dari 0,05 yang berarti tidak terdapat pengaruh antara variabel bebas 
terhadap absolute residual. Dengan demikian, model yang dibuat tidak mengandung gejala heteroskedastisitas dapat dilihat pada Tabel 10.

Nilai koefisien regresi masing-masing variabel bebas bernilai positif dengan nilai signifikansi uji t kurang dari 0,05. Hal ini menunjukkan bahwa semua variabel bebas memiliki pengaruh positif yang signifikan terhadap variabel terikat. Berikut penjelasan mengenai hasil analisis regresi berganda, terdiri atas koefisien determinasi $\left(\mathrm{R}^{2}\right)$, uji kelayakan model (uji $\mathrm{F}$ ), dan uji hipotesis (uji t). Hasil analisis regresi linear berganda dapat dilihat pada Tabel 11 berikut ini.

Tabel 11. Hasil Analisis Regresi Linier Berganda

\begin{tabular}{|c|c|c|c|c|c|}
\hline \multirow[t]{2}{*}{ Variabel } & \multicolumn{2}{|c|}{$\begin{array}{l}\text { Unstandardized } \\
\text { Coefficients }\end{array}$} & \multirow{2}{*}{$\begin{array}{l}\text { Standardized } \\
\text { Coefficients } \\
\text { Beta }\end{array}$} & \multirow[t]{2}{*}{$t$} & \multirow[t]{2}{*}{ Sig. } \\
\hline & $\beta$ & Std. Error & & & \\
\hline (Konstanta) & 0,741 & & & 0,140 & 0,889 \\
\hline $\begin{array}{l}\text { Kecerdasan } \\
\text { emosional }\left(X_{1}\right)\end{array}$ & 0,181 & 0,067 & 0,214 & 2,689 & 0,008 \\
\hline $\begin{array}{l}\text { Gaya belajar } \\
\text { visual }\left(X_{2}\right)\end{array}$ & 0,613 & 0,279 & 0,177 & 2,197 & 0,029 \\
\hline $\begin{array}{l}\text { Gaya belajar } \\
\text { auditorial }\left(X_{3}\right)\end{array}$ & 0,993 & 0,180 & 0,362 & 5,514 & 0,000 \\
\hline $\begin{array}{l}\text { Gaya belajar } \\
\text { kinestetik }\left(\mathrm{X}_{4}\right)\end{array}$ & 0,697 & 0,199 & 0,230 & 3,504 & 0,001 \\
\hline R Square & & & 0,338 & & \\
\hline Adjusted R Square & & & 0,322 & & \\
\hline F hitung & & & 21,175 & & \\
\hline Signifikansi F & & & 0,000 & & \\
\hline
\end{tabular}

Sumber : Data Penelitian, 2019

Koefisien determinasi $\left(\mathrm{R}^{2}\right)$ digunakan untuk mengetahui dan mengukur kemampuan model dalam menerangkan variasi variabel independen. Besarnya pengaruh variabel bebas terhadap variabel terikat yang ditunjukkan oleh nilai determinasi total (R Square) sebesar 0,338 mempunyai arti bahwa sebesar 33,8\% variasi tingkat pemahaman akuntansi dipengaruhi oleh variasi kecerdasan emosional, gaya belajar visual, gaya belajar auditorial, dan gaya belajar kinestetik, sedangkan sisanya sebesar $66,2 \%$ djelaskan oleh faktor lain yang tidak dimasukkan ke dalam model.

Berdasarkan hasil analisis pengaruh kecerdasan emosional pada tingkat pemahaman akuntansi diperoleh nilai signifikasi sebesar 0,008 dengan nilai koefisien beta 0,181. Nilai Signifikansi 0,008< 0,05 mengindikasikan bahwa $\mathrm{H}_{0}$ ditolak dan $\mathrm{H}_{1}$ diterima. Hasil ini mempunyai arti bahwa kecerdasan emosional berpengaruh positif dan signifikan pada tingkat pemahaman akuntansi.

Berdasarkan hasil analisis pengaruh gaya belajar visual pada tingkat pemahaman akuntansi diperoleh nilai signifikansi sebesar 0,029 dengan nilai koefisien beta 0,613. Nilai Signifikansi 0,029<0,05 mengindikasikan bahwa $\mathrm{H}_{0}$ ditolak dan $\mathrm{H}_{2}$ diterima. Hasil ini mempunyai arti bahwa gaya belajar visual berpengaruh positif dan signifikan pada tingkat pemahaman akuntansi. 
Berdasarkan hasil analisis pengaruh gaya belajar auditorial pada tingkat pemahaman akuntansi diperoleh nilai signifikansi sebesar 0,000 dengan nilai koefisien beta 0,993. Nilai signifikansi $0,000<0,05$ mengindikasikan bahwa $\mathrm{H}_{0}$ ditolak dan $\mathrm{H}_{3}$ diterima. Hasil ini mempunyai arti bahwa gaya belajar auditorial berpengaruh positif dan signifikan pada tingkat pemahaman akuntansi.

Berdasarkan hasil analisis pengaruh gaya belajar kinestetik pada tingkat pemahaman akuntansi diperoleh nilai signifikansi sebesar 0,001 dengan nilai koefisien beta 0,697. Nilai signifikansi 0,001<0,05 mengindikasikan bahwa $\mathrm{H}_{0}$ ditolak dan $\mathrm{H}_{4}$ diterima. Hasil ini mempunyai arti bahwa gaya belajar kinestetik berpengaruh positif dan signifikan pada tingkat pemahaman akuntansi.

Hipotesis $1\left(\mathrm{H}_{1}\right)$ menyatakan bahwa kecerdasan emosional berpengaruh positif pada tingkat pemahaman akuntansi. Kecerdasan emosional ditandai oleh kemampuan pengenalan diri, pengendalian diri, motivasi diri, empati dan keterampilan sosial yang mempengaruhi seberapa besar mahasiswa dalam memahami akuntansi. Kecerdasan emosional dalam seseorang mampu untuk mengetahui dan menanggapi perasaan mereka sendiri dengan baik, mampu membaca dan mengahadapi perasaan orang lain dengan efektif. Hal ini berarti $\left(\mathrm{H}_{1}\right)$ diatas diterima, semakin tinggi kecerdasan emosional mahasiswa tersebut, maka akan semakin tinggi pula pemahaman akuntansinya. Penelitian ini mendukung teori kognitif yang menjelaskan bahwa proses pemikiran serta pengaruh faktor internal dan eksternal dalam menghasilkan belajarnya seorang individu, selain itu faktor internal meliputi kecerdasan yaitu salah satunya yaitu kecerdasan emosional. Kecerdasan emosional yang lebih berpengaruh yaitu motivasi diri dan keterampilan sosial karena mahasiswa yang memiliki keterampilan sosial yang baik akan berhasil di dalam kehidupan dan memiliki motivasi untuk terus belajar. Namun, mahasiswa yang memiliki keterampilan emosi yang kurang baik, akan kurang memiliki motivasi untuk belajar sehingga dapat merusak kemampuannya untuk memusatkan perhatian pada tugas-tugas individu tersebut sebagai mahasiswa.

Kecerdasan emosional memungkinkan seseorang untuk memutuskan dalam situasi apa dirinya berada lalu bersikap secara tepat didalamnya. Kecerdasan emosional memberikan kesadaran mengenai perasaan milik diri sendiri dan juga perasaan milik orang lain. Kecerdasan emosional memberikan rasa empati, cinta, motivasi dan kemampuan untuk menanggapi kesedihan atau kegembiraan secara tepat. Oleh karena itu, mahasiswa yang memiliki keterampilan emosi yang baik akan berhasil di dalam kehidupan dan memiliki motivasi yang tinggi untuk terus memahami setiap pelajaran yang terus diajarkan. Sedangkan, mahasiwa yang memiliki keterampilan emosi yang kurang baik, akan kurang memiliki motivasi untuk belajar, sehingga dapat mengganggu kemampuannya untuk memusatkan perhatian pada tugas-tugas individu sebagai mahasiswa. Hasil penelitian ini sesuai dengan penelitian yang dilakukan oleh Junifar (2015) yang menyatakan bahwa kecerdasan emosional berpengaruh positif pada tingkat pemahaman akuntansi.

Hipotesis $2\left(\mathrm{H}_{2}\right)$ menyatakan bahwa gaya belajar visual berpengaruh positif pada tingkat pemahaman akuntansi. Gaya belajar visual yang dimiliki mahasiswa lebih mengaktifkan indera penglihatan (mata) untuk melihat langsung cara penyampaian dosen didalam kelas dengan memperoleh informasi 
melihat data teks seperti tulisan dan huruf agar dapat memahami akuntansi. Hal ini berarti $\mathrm{H}_{2}$ diterima, semakin baik gaya belajar visual maka seseorang tersebut dapat mengambil langkah-langkah penting dalam dirinya agar dapat belajar lebih cepat dan lebih mudah sehingga dapat memperoleh pemahaman yang diinginkan. Penelitian ini mendukung teori kognitif yang menjelaskan bahwa proses pemikiran dan perbedaan kondisi mental serta pengaruh faktor internal dan eksternal dalam menghasilkan belajarnya seorang individu, selain itu faktor internal meliputi salah satunya yaitu gaya belajar visual hal ini mengindikasikan bahwa seseorang yang memiliki gaya belajar visual biasanya lebih cenderung memiliki pemahaman yang mendalam terhadap materi yang didapatkannya.

Gaya belajar visual adalah suatu bentuk gaya belajar dengan cara melihat, mengamati, dan memandang suatu objek yang dipelajari. Kekuatan gaya belajar visual terletak pada indra penglihatan, bagi orang yang memiliki gaya belajar ini, mata adalah alat yang paling peka untuk menangkap setiap gejala atau stimulus (rangsangan) belajar. Orang dengan gaya belajar visual senang dengan berbagai ilustrasi, membaca intruksi, mengamati gambar-gambar meninjau kejadian secara langsung dan sebagainya.

Hasil penelitian ini sesuai dengan penelitian yang dilakukan oleh Bire et al. (2014) yang menyatakan bahwa gaya belajar visual berpengaruh positif pada tingkat pemahaman akuntansi. Selain ini didukung pula dengan penelitian yang dilakukan oleh Ardila (2015) menyatakan bahwa gaya belajar visual berpengaruh terhadap belajar akuntansi.

Hipotesis $3\left(\mathrm{H}_{3}\right)$ menyatakan gaya belajar auditorial berpengaruh positif pada tingkat pemahaman akuntansi. Gaya belajar auditorial mahasiswa lebih dominan dalam menggunakan indera pendengaran untuk melakukan aktivitas belajar agar memudahkan dalam memahami akuntansi. Hal ini berarti $\left(\mathrm{H}_{3}\right)$ diatas diterima, semakin baik gaya belajar auditorial maka akan semakin lebih mudah mendengarkan apa yang disampaikan oleh orang lain, dengan demikian belajar melalui mendengar sesuatu seseorang lebih cepat menangkap apa yang diberikan di kelas. Penelitian ini mendukung teori kognitif yang menjelaskan bahwa proses pemikiran dan perbedaan kondisi mental serta pengaruh faktor internal dan eksternal dalam menghasilkan belajarnya seorang individu, selain itu faktor internal meliputi salah satunya yaitu gaya belajar auditorial hal ini mengindikasikan bahwa seseorang memerlukan suasana yang tenang dan hening sebelum mempelajari materi yang diberikan dengan demikian seseorang akan mudah menghafal materi yang diajarkan dengan mengucapkannya berkalikali. Diantara tiga macam gaya belajar, yang paling berpengaruh yaitu gaya belajar auditorial karena gaya belajar ini benar-benar menempatkan pendengaran sebagai alat utama untuk menyerap informasi tertentu, jadi seseorang harus mendengarkan terlebih dahulu, artinya seseorang harus mendengar baru kemudian bisa mengingat dan memahami informasi yang diterima.

Gaya belajar auditorial adalah gaya belajar yang mengandalkan pendengaran untuk memahami sekaligus mengingat materi perkuliahan, seseorang yang memiliki gaya belajar auditorial mereka sangat menikmati saatsaat mendengarkan apa yang disampaikan oleh orang lain. Ciri-ciri dari seseorang yang memiliki gaya belajar auditorial yaitu salah satunya sering 
menggerakkan bibir dan mengucapkan tulisan dibuku ketika membaca, senang membaca dengan keras dan mendengarkan sesuatu, dan dapat mengulangi kembali dan menirukan nada, birama, dan warna suara dengan mudah. Hasil penelitian ini sesuai dengan penelitian yang dilakukan oleh Sugiarti (2016) dan Bire et al. (2014) yang menyatakan bahwa gaya belajar auditorial berpengaruh positif pada tingkat pemahaman akuntansi.

Hipotesis $4\left(\mathrm{H}_{4}\right)$ menyatakan bahwa gaya belajar kinestetik berpengaruh positif pada tingkat pemahaman akuntansi. Gaya belajar kinestetik lebih mudah menangkap pelajaran atau mengambil tindakan, selain itu gaya belajar ini berhubungan dengan praktik atau pengalaman belajar secara langsung mengenai pemahaman akuntansi. Hal ini berarti $\left(\mathrm{H}_{4}\right)$ diatas diterima, semakin baik gaya belajar kinestetik seseorang maka seseorang akan mampu mengemukakan pendapatnya dan antusias dalam mengikuti mata kuliah. Penelitian ini mendukung teori kognitif yang menjelaskan bahwa proses pemikiran dan perbedaan kondisi mental serta pengaruh faktor internal dan eksternal dalam menghasilkan belajarnya seorang individu, selain itu faktor internal meliputi salah satunya yaitu gaya belajar kinestetik hal ini mengindikasikan bahwa gaya belajar kinestetik lebih menekankan pada kejelasan makna dan tujuan sebelum mempelajari sesuatu hal dengan demikian gaya belajar ini lebih menjelaskan melalui praktek langsung untuk dapat memahaminya.

Gaya belajar kinestetik mengharuskan individu yang bersangkutan menyentuh sesuatu yang memberikan informasi tertentu agar bisa mengingatnya. Tentu saja ada beberapa model belajar seperti ini yang tak semua orang bisa melakukannya. Karakter pertama adalah menempatkan tangan sebagai alat penerima informasi utama agar bisa terus mengingatnya, hanya dengan memegang nya saja seseorang yang memiliki gaya belajar seperti ini bisa menyerap informasi tanpa harus membaca penjelasannya. Gaya belajar kinestetik memiliki ciri-ciri yang menonjol yaitu salah satunya berbicara dengan perlahan, menyentuh orang untuk mendapatkan perhatian mereka, berdiri dekat ketika berbicara dengan orang, selalu berorientasi dengan fisik dan banyak bergerak, menghafal dengan cara berjalan dan melihat, menggunakan jari sebagai penunjuk ketika membaca, banyak menggunakan isyarat tubuh, tidak dapat duduk diam untuk waktu lama, memungkinkan tulisannya jelek, dan ingin melakukan segala sesuatu.

Hasil penelitian ini sesuai dengan penelitian yang dilakukan oleh Bire (2014) yang menyatakan bahwa gaya belajar kinestetik berpengaruh positif pada tingkat pemahaman akuntansi. Selain ini didukung pula dengan penelitian yang dilakukan oleh Arif (2017) menyatakan bahwa gaya belajar kinstetik berpengaruh terhadap pemahaman akuntansi.

Implikasi hasil penelitian ini mendukung teori kognitif yang menyatakan bahwa tingkat pemahaman akuntansi di pengaruhi oleh faktor internal yaitu kecerdasan emosional, gaya belajar visual, gaya belajar auditorial dan gaya belajar kinestetik. Implikasi praktis dalam penelitian ini diharapkan akan memberikan tambahan informasi dan masukan, serta referensi bagi semua pihak khusunya bagi mahasiswa akuntansi bahwa kecerdasan emosional, gaya belajar visual, gaya belajar auditorial dan gaya belajar kinestetik dapat mengkontribusi terhadap tingkat pemahaman akuntansi yang selama ini diajarkan di perguruan 
tinggi agar mampu bersaing dalam dunia kerja. Penelitian ini memberikan masukan bahwa diantara kecerdasan emosional, gaya belajar visual, gaya belajar auditorial dan gaya belajar kinestetik yang lebih efektif untuk diterapkan dalam belajar adalah gaya belajar auditorial.

\section{SIMPULAN}

Hasil analisis data dan pembahasan yang telah diuraikan pada bab-bab sebelumnya mengenai Pengaruh Kecerdasan Emosional, Gaya Belajar Visual, Gaya Belajar Auditorial dan Gaya Belajar Kinestetik pada Tingkat Pemahman Akuntansi, dapat disimpulkan bahwa Kecerdasan emosional mahasiswa akuntansi berpengaruh positif pada tingkat pemahaman akuntansi. Gaya belajar visual mahasiswa akuntansi berpengaruh positif pada tingkat pemahaman akuntansi. Gaya belajar auditorial mahasiswa akuntansi berpengaruh positif pada tingkat pemahaman akuntansi. Gaya belajar kinestetik mahasiswa akuntansi berpengaruh positif pada tingkat pemahaman akuntansi.

Berdasarkan hasil analisis dapat disarankan untuk peneliti selanjutnya diharapkan menggunakan responden dari Universitas lainnya, di luar Universitas Udayana, agar hasil penelitian ini dapat dibandingkan. Peneliti selanjutnya juga diharapkan menambah variabel faktor eksternal, seperti lingkungan belajar.

\section{REFERENSI}

Akbar, M., Ashgar, A. ., Ejaz., A. K., \& Akhtar, M. (2011). Relationship Between Emotional Intelligence and Academic Achievment Among Higher Secondary Students. Pacistan Journal of Pyscology, 42(2), 43-56.

Ardila, N., Buwono, S., \& Rosyid, R. (2015). Pengaruh Gaya belajar Terhadap Belajar Akuntansi Siswa SMAN 1. Jurnal Pendidikan Dan Pembelajaran, 4(4), $1-20$.

Ariantini, K. M., Sujana, E., \& Herawati, N. T. (2014). Pengaruh Kecerdasan Emosional dan Minat Membaca terhadap Tingkat Pemahaman Akuntansi dengen Kepercayaan Diri sebagai Variabel Moderasi. Journal S1 Akuntansi Universitas Pendidikan Ganesha, 2(1), 1-20.

Arif, B. (2017). Pengaruh Gaya Belajar Tehadap Pemahaman Dasar Akuntansi Mahasiswa. Jurnal Universitas Lampung, 1(1), 1-20.

Artana, B. (2014). Pengaruh Kecerdasan Intelektual (IQ), Kecerdasan Emosional (EQ), Kecerdasan Spritual (SQ), dan Perilaku Belajar terhadap Pemahaman Akuntansi. E-Journal S1 Akuntansi Universitas Pendidikan Ganesha, 2(1), 54-56.

Bire, A. L., Geradus, U., \& Bire, J. (2014). Pengaruh Gaya Belajar Visual, Auditorial, Dan Kinestetik Terhadap Tingkat Pemahaman Akuntansi dan Prestasi Belajar Siswa. Jurnal Pendidikan, 44(2), 168-178.

Brackett, M. A., Rivers, S. E., \& Salovey, P. (2011). Implicational for Personal, Sosial, Academic, and Work Place Success. The Journal of Sosial and Personality Psichology Compass, 5(1), 88-103.

Chen, C., Jones, K. T., \& Xu, S. (2018). The Association Between Students' Style of Learning Preferences, Social Presence, Collaborative Learning and Learning Outcomes. Journal of Educators Online, 15(1). https://doi.org/10.9743/jeo2018.15.1.3 
Dewi, N. P. R. A., \& Wirama, D. G. (2016). Kepercayaan Diri Sebagai Pemoderasi Pengaruh Kecerdasan Emosional dan Perilaku Belajar Pada Tingkat Pemahaman Akuntansi. E-Jurnal Akuntansi Universitas Udayana, 16(1), 615644.

Fred, P., Guina, S., \& Alford, S. (2012). Illustrations in Financial Accounting Textbooks: Function and Placement Interact to Affect Student Learning. Issues in Acounting Education, 27(4), 999-1017.

Ihsan, D., \& Diem, C. D. (2016). The learning styles and language learning strategies of the EFL students at tertiary level. Journal of Education, 4(1), 1224.

Isnaeni, F. S. (2017). Pengaruh Gaya Belajar Visual, Auditori, Dan Kinestetik Terhadap Prestasi Belajar Siswa. Jurnal Universitas Negeri Yogyakarta, 1(1), 112.

Junifar, N. (2015). Pengaruh Kecerdasan Emosional, Kecerdasan Spiritual, dan Perilaku Belajar terhadap Tingkat Pemahaman Akuntansi. Jurnal Ilmu Dan Riset Akuntansi, 4(10), 1-20.

Khajeh, N., Naami, A., Beshlideh, K., Esmaeil, S., \& Sheikh, H. (2014). Effects of emotional intelligence education on interpersonal conflict and work- family facilitation in an industrial company ' s staff. European Journal of Accounting, Auditing and Finance Research, 2(3), 3166-3175.

Khalid, H. (2011). Priciples of Poultry Science Poulry Industry. Journal Diyala University, 1(2), 62.

Kustiani, L., \& Brihandhono, A. (2017). The Relation of Learning Styles, Learning Interests and Learning Methods Used by Students with the Level of Emotional Intelligence and Grade among Students: Case Study of Economy Class at Smk Ma'arif Malang, Indonesia. Mediterranean Journal of Social Sciences, 8(5), 19-29. https:// doi.org/10.1515/mjss-2017-0020

Nath, S., Soumitra, G., \& Shymanta, D. (2015). Relationship Between Intelligence, Emotional Intelligence and Academic Perfomance Among Medical Interns. Open Journal of Psychiatry and Allied Science, 1(6), 96-100. https://doi.org/10.5859/2394-2061.2015.00004.X.

Nzesei, M. M. (2015). A Correlation Study Between Learning Styles and Academic Performance. Journal of Psych, 1(1), 70-89.

Peker, M., \& Mirasyedioglu, S. (2008). Preservice Elementary School Teachers Learning Styles and Attitudes Towards Mathematics. Eurasian Journal of Mathematics, Science, and Technology Education, 4(1), 21-26.

Polat, Y., Peker, A. A., Özpeynirci, R., \& Duman, H. (2015). The Effect of Learning Styles of Accounting Education Students on their Performance: A Field Study. Social and Behavioral Sciences, 174(1), 1841-1848. https://doi.org/10.1016/j.sbspro.2015.01.846

Pratiwi, D. (2014). Gaya Belajar Dominan Pada Siswa Berprestasi Dalam Kegiatan Siswa Yang Memiliki Gaya Belajar Di SD Negeri 2 Gombong Tahun Ajaran 2013/2014. Jurnal FKIP, 7(3), 1-20.

Ramlah. (2014). Pengaruh Gaya Belajar Dan Keaktifan Siswa Terhadap Pemahaman Akuntansi (Survey Pada SMP Negeri di Kecematan Klari Kabupaten Karawang). Jurnal Ilmiah, 1(3), 1-20.

Salehi, M. (2016). A Study of The Effect of Education and Academic Environment 
on Emotional Intelligence on Accounting Student in Iran. International Education Studies, 9(1), 182-188.

Santoso, A. L. (2018). Emotional Intelligence and Job Performance of Accounting Students Undertaking Internships. Journal of Management and Marketing Review, 3(1), 40-47.

Satria, M. R. (2017). Pengaruh Kecerdasan Emosional Terhadap Tingkat Pemahaman Akuntansi pada Mahasiswa Akuntansi di Kota Bandung. Jurnal Amwaluna, 1(1), J. Amwaluna.

Shoemaker, N., Austin, S. F., \& Kellu, M. (2015). Emphasis On Differences Between Majors. Journal of College Teaching E Learning, 12(4), 223-230.

Sinarti, S., \& Sari, U. D. M. (2019). The Influence of Emotional Intelligence on the Accounting Comprehension: Gender Based Study. Journal of Applied Managerial Accounting, 1(1), 30-36. https:// doi.org/10.30871/jama.v1i1.1236

Syofyan, R., \& Siwi, M. K. (2018). The Impact of Visual, Auditory, and Kinesthetic Learning Styles on Economics Education Teaching. Advances in Economics, Business and Management Research, 57(1), 642-649. https://doi.org/10.2991/ piceeba-18.2018.17

Thomas, W. (2002). Factors Influencing Student Learning in Introductory Accounting Classes: A Comparison of Traditional and Nontraditional Students. Issues in Accounting Education, 13(2), 357-374.

Tucker, M. (2014). Accounting of EI : Does Emotional Intelligence Predict Greater Intercultural Growth. Journal of International Business and Cultural Studies, $8(2), 20$.

Visser, B. (2015). Emotional Intelligence: The Role of Accounting Education and Work Experience. Issues in Accounting Education, 26(2), 1-12. 